\title{
Urban Solid Waste Management in Dili Community
}

\author{
Zulmira Ximenes Da Costa \\ Researcher in Water Environment and Lecturer in \\ the Department of Informatics Engineering, Faculty \\ Engineering Science and Technology \\ Universidade Nacional Timor Lorosa'e- UNTL Dili, \\ Timor Leste
}

\author{
Bia Ble Hitu Carvalho De Jesus \\ Researcher and Lecturer in the Department of Economics, \\ Faculty of Economy \\ Universidade Nacional Timor Lorosa'e- UNTL \\ Dili, Timor Leste
}

\begin{abstract}
Urban solid waste is one of the big issues in Dili community, such as poor management performed by state and lack of understanding by communities on solid waste deposits. Therefore, this study aims to gather and describe the relations between the existed waste management system and communities understanding and satisfaction with adopted system by the Ministry of State Administration. Furthermore, to raise public's awareness on solid waste impacts for urban communities. To mitigate, we introduce an adequate, integrated and sustainable system to reduce solid waste problems in urban communities. In our methodology, we distributed questionnaires for 431 respondents of four administrative posts within Dili municipality, resulting $72 \%$ of communities are agreed and satisfied with the current government system on solid waste management in Dili community.
\end{abstract}

The generalized way to manage solid waste is transported to public open dump and burning. Related to the waste impacts, health and environment are urgently needed to solve in Dili community. The most of communities are with irresponsible behavior and lack of participation in solid waste management, recycling and reutilization. $49 \%$ of communities didn't understood the separation or recycling of solid waste and $\mathbf{8 9 . 8 \%}$ were agree and available to pay the $3 R$ 's applied system to change communities' behavior on solid waste management. Further technical solution, we propose Artificial Neural Network (ANN) technique to predict solid waste generation in urban areas in our future works.

Keywords: Urban, solid waste management, artificial neural network.

\section{INTRODUCTION}

Solid waste is one of the largest and often most visible problems in the Dili community and since Timor-Leste's independence until today solid waste was continuing spread in Dili capital due to lack of communities understanding on solid waste treatment in adequate places.

Solid waste or wastes are unused materials that are encounter in solid state, or are solid objects that have already lost value at the time where their contents were consumed by consumers. Solid waste is generated by human activities and natures. Those wastes that generated by human activities are from domestics, hospitals, commercials, agricultures, industries and sweeping services. However, as long as there is no process of recovery of these wastes, they are capable of constituting health, environment, economic and aesthetic problems.

According to the Decree Law No. 5/2011 by the government of Timor-Leste has stated the definition of waste. "Waste as any solid, liquid, gas or radioactive matters that cause transformations when unloaded in environment, and are results of individuals or private and publics institutions activities". Related to this definition, the waste classification according to its origin such as a domestic or hospital or another type of waste because they are different, as well the dangerousness is depending on its origin. Solid waste is all the daily waste which derived from the human or un-human activities. Monteiro et al (2001) has presented that solid waste can be classified according to its origin and they are grouped into five classes, such as domestic, commercial, public, special domestic (construction of waste, batteries, lamps, tires), special sources (industrial, radioactive, harbours, airports and road terminals, agriculture and health service centres).

In the era of globalization with the rise of technology innovation, the waste problem has become a global issue, because it happens in all countries including in Timor-Leste. Finally, after independence until today, the accumulation of solid waste in capital shows as a problem that there is no solution to solve. In reality, the accumulation of these wastes determined by various factors, such as rural emigration to Dili capital indicated that there is an increase in population number[4](Timor-Leste Population Census Data, 2010) and economic composition which is one of the most important factors, given the model of adopted development, the consumption pattern and contemporary lifestyle popularized by increased industry.

In case of Timor-Leste, the worsening of this waste due to community attitude and the system adopted by the government is still in a conventional or traditional way. The community is not yet aware of the importance and impacts of solid waste. As a result, you always find people who dispose of waste anywhere and noted that mostly along the road sides and the solid waste circuit has very similar characteristics. The waste is scattered in the common public areas, on the roads and collected by scavengers and animals. Timor-Leste as a young country, in the process of development is still caused by the limitations of qualified human resources, limited knowledge of government agencies and limited of public service infrastructures. Basically, the solid waste treatment process is most treated with traditional ways and it has not yet adopted an integrated management system to manage solid waste in Dili community.

Therefore, this study with the aims to gather and describe 
the existing solid waste management systems in Dili communities and to measure community understanding and satisfaction with the adopted solid waste management system by the Ministry of State Administration of the government of Timor-Leste. And also to know the impacts caused by solid waste and the introduction of a more appropriate, integrated and sustainable system to reduce solid waste problems in Dili community.

\section{METHODOLOGY}

This is a qualitative study of exploratory analysis which held in Dili Community, with a sample of 431 individuals. It was used questionnaire and interview for data and information collection. Several variables were considered and measured in different scales, namely:

a. Demographic characteristics, such as municipality, neighborhood, gender, age, income, length of time the dwelling, marital status, household number.

b. Waste management situation in neighborhood or in house, such as waste removal, waste recollection process, responsibility for collecting waste, type of waste and waste treatment.

c. Impacts caused by waste, such as for environmental (pollution, water contamination, enormous volumes of waste, bad smell), health (high number of patients, several diseases).

d. Presentation of an integrated and adequate system to manage solid waste in each neighborhood: The municipality applies the system in the neighborhood, study the availability of people to pay for the service and the amount they could pay for service.

e. Evaluation of waste management services provided by the government: Partnership between government and a Chinese company to treat the waste incineration; community satisfaction grade; control of time to collect the waste, results of councils cleaning services financing, energetic form valorization importance, factors that influences the generation of waste.

\section{RESULTS}

\section{A. Demographic Character}

The sample was selected randomly in the following Administrative Posts: Vera Cruz (23.67\% of respondents), Nain-Feto (25.06\%, of respondents) Dom Aleixo (25.99\% of respondents) and Cristo Rei (25.29\% of respondents). The respondents were mostly male $(58.70 \%)$ and female were $41.30 \% .80 .5 \%$ were permanent residents.

The age average is 35 years old, ranging between 18 and 76 years old; the majority of the respondents live in Dili for less than 6 years. Household average are made up of 5 adults and children average 3 , ranging from 1 child up to 5 . The level of education is mostly constituted by graduates 33.6\%.

Households earn income is based on specific work; the main source of family income is acquired by the professionals that work on public function and on nongovernmental institutions (59.86 \%). However, the variability is large, in which (20.65) public employers, 10.67\% farmers, and most of respondent's income is between 101 and 200 US\$.

\section{B. Community Behavior beyond Solid Waste}

There are many determinants for waste accumulation in the villages. Among the most significant are: public cleaning service is handled by the municipality services with incipient measures (56\%), the increasing of population (41\%) (More people more waste). Also the community attitude contributes to increase the volume of waste (31\%). Other reasons like the unfamiliarity with 3Rs program as a policy adopted by the government; community consumption pattern and no existing monitoring (less than 30\%). There is $94 \%$ of recollect the waste is from the residence. Common bins are used by $43 \%$ of respondents to dispense household waste, trash burning has a significant number (36\%), throw it in the river, on the street or bury it in the backyard cover approximately $17 \%$. The waste recollecting from home is $97 \%$. The daily waste recollecting is $60.1 \%$.

\section{Waste Management Situation in Neighborhood}

Regarding the waste separation habits, there is less respondents separating waste due to the absence of a recycling industry in Dili. Of the interviewed households, only $45.9 \%$ separates the waste; the most doesn't do it (48.7\%). However, the type of waste which is separated is cans, organic, glass, plastic and paper. The organic waste is reused, mostly for animal feed (31\%) and fertilizer (27\%). If it exists the opportunity to sell separate waste, only a small percentage of people would do it. Regarding the respondents who do separation, most of them most would sell the cans (72\%). This is very important for policy that want to base strategies in financial incentives. Community could be encouraged to sell their own waste for recycling companies reducing the volume of waste. There is already a private enterprise "Smart product" in Manleuana that transforms plastics and bottles in raw materials and exports it to Indonesia. (TVTL, Monday, March 23 2015).

In East Timor the government is still practicing the waste management in a traditional way. The government is only responsible for the waste management. They present now the waste management model that is implemented by the Timor Leste government to manage solid waste in Tibar. In addition, they present the waste management model that will be applied in Timor.

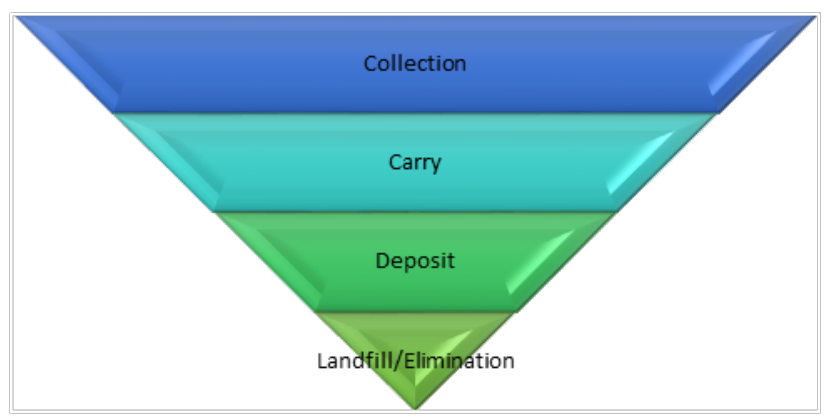

Fig. 1 Waste Management model of East Timor 


\section{Final Destination of Waste Management (Timor-} Leste)

In Dili the waste management is still incipient and of government responsibility. The waste is collected in common open trucks in the city neighborhoods, deposited in open bins and transported than to Tibar landfill. The landfill does not have any preparation and it is in reality a large open burning.

The final destination of the urban solid waste in Dili community is open burning in Tibar, so it is burning of unwanted materials that causes smoke and other emissions to be related directly into the air and environment. The materials of the burning compose of outdoor piles, burning in a burn barrel and the use of incinerators which have no pollution control devices and as such release the gaseous by products directly into the free atmosphere.

\section{E. $\quad$ Solid Waste Impacts}

Based on the analysis results there is a sensibility in respondents to the waste problem. In fact, respondents have responsibility in the management of their houses waste. However, this is still a little matter of low priority. The problem that most urgently needs solution is health (84\%); pollution appears as the second most referred problem (58\%), tourism (47\%) and at last the social problem (42\%).

\section{- Impact on Health}

Regarding health problems caused by waste (81.3\%). Respiratory diseases (58\%), malaria (23\%), dengue 22\%.

The Director of the National Community Development and of support to councils also reports that most of workers that collect waste has tuberculosis disease with 7 confirmed deaths. The main reason for the transmission of this disease is the daily direct contact with waste. This information was also confirmed by sanitation department of Dili municipality - 15 workers caught tuberculosis caused by waste.

The waste collection can also attract many people to collect recyclable waste to own reuse. There is two types of collectors: the personal ones composed by adults (43.72 \%) and children (36.93\%); the animal scavengers mostly dogs (42.26\%).

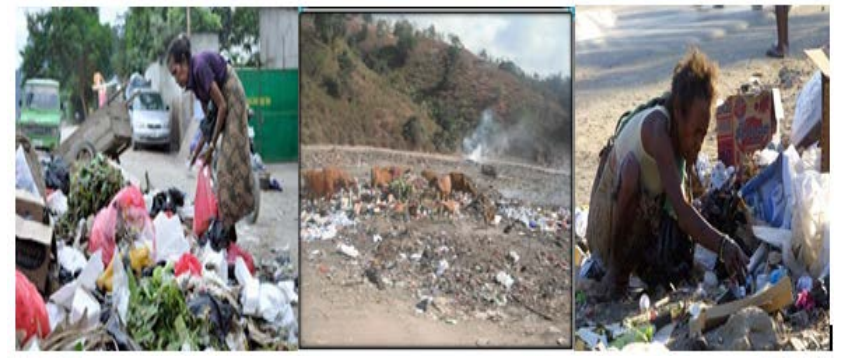

Fig 2. The volunteer pickers are picking up trash

According to Heller and Catapreta [6](1999) there is a relation between inadequate management of waste and the existence of infectious and parasitic diseases. The absence of collection of solid waste added to their improper disposal is a major risk factor for public health, especially in the outskirts of large urban centers, where the population with the lowest income is heavily.

\section{- Impact on the Environment}

In environmental impacts, the one that is referred as more urgent to solve is the increasing of waste volume (42\%), than appears air pollution (23\%), traffic congestion (because difficult the circulation) (22\%), water contamination (20\%), decrease of water supply and an inadequate sanitation system (sewerage) (15\%);

Inappropriate treatment of waste can cause negative impacts in the environment which contaminate water, pollute soil and cause bad smell. Result of this pollution is the decrease of environmental quality. In addition to environmental problems are the social problems through the excluded society that seeks in waste materials to sell (paper, plastic, cans, etc.); sometimes people also seek food, or remains for consumption often damaged and contaminated, showing the apex of human degradation.

These impacts are dependent on waste production rate: a 2014 study developed by the Asian Development Bank shows that daily arrives to Tibar bin more than 120 tons of waste, so the management of municipal waste is a growing challenge for the capital authorities. It means that a person produces $0.51 \mathrm{~kg}$ of waste per day.

F. Assessment for the management services provided by the municipality

We had analyzed the community grade of satisfaction with the current waste management provided by the municipalities. There are satisfied $71.46 \%$ of people what means that Dili community is satisfied with the mechanism established by the municipality.

Although most of the answers are satisfied with the services provided by the municipality, $55.9 \%$ of respondents said that the government hadn't monitored or controlled the regulation in the community. This means that the government is permissive to community inadequate behavior beyond the waste management (namely the collection). The director of the sanitation department of Dili municipality has confirmed that they didn't apply the penalties to communities that do not obey to regulation because this law has not yet been enacted and approved by the government until now.

Regarding of the partnership between government and a Chinese Company to use a waste incineration process using a thermal system, as a valorization of an energetic form. The opinion of the community sample relating this matter was that this process could improve the waste management (44\%).

The community opinion about government financing for cleaning activities and reduction of waste volume in councils, $32.71 \%$ says that with this incentive the government is creating a good dependency attitude in the communities in relation to cleaning their own neighborhoods. This means that communities will carry out cleaning activities with some incentives.

\section{G. Proposal of an integrated and adequate waste management policy}

Regarding the application of an integrated and adequate policy of waste management it was presented to the inquired the 3R system (Reduce, Reutilize and Recycle). Most of them agrees with this system (91\%); It was asked to them how they were available to contribute to the solution of the waste 
problem. $73,8 \%$ says that they would pay an amount for this system application.

Than they were asked the amount they were available to pay for the system sustainability. $18,6 \%$ were available to pay an amount between $\$ 2,05$ to $\$ 5$. So, $34 \%$ says that this issue is a government responsibility so they weren't available to pay for that. $77,49 \%$ would contribute for a change in the community's behavior beyond the waste problem.

About the importance of the waste service payment 71,5\% said that would be important to establish an amount based on the waste volume produced by each person what means that could be implemented the polluter payment principle (the payment was based on the amount of produced waste). Probably this measure would contribute for a in waste volume.

Currently in East Timor there are some non-governmental institutions that do waste separation and treatment. Organic fertilize ris produced by H3R, Unipessoal Lda, company, in Tibar. Cans are collected by Besitua company in Aitarak Laran and then is exported to Singapore. Bottles are collected by 'Timor Hopeseller Leadership Center' of Timor-Leste's local organization that Works together with UNDP, and are exported to Kupang in Indonesia.

After conduct this study, consider that number of population, generated of urban solid waste, budget, number of transportation, human resources and quantity of the waste has been considered as most important factor in solid waste generation in the urban area.

The next steps of this research is will be make prediction of the solid waste quantity. As we know that the population is increasing day by day solid waste generation is also increasing specifically in the urban area. This is very big question in front of Ministry of state Administration and Lead of Municipality that how to fight this problem. It is very important to predict the quantity of solid waste in the upcoming year to implement the adequate solid waste management system in Timor Leste.

\section{H. Prediction of solid waste generation by using the Artificial Neural Network (ANN)}

This artificial neural network (ANN) is to predict solid waste generation in urban area. We may consider that human vision, which is an information-processing task. It is the function of the visual system to provide a representation of the environment around us. The way in which the neurons of a neural network will structure and well link with the learning algorithm using to train the network and will use algorithms to design of neural networks as being structure.

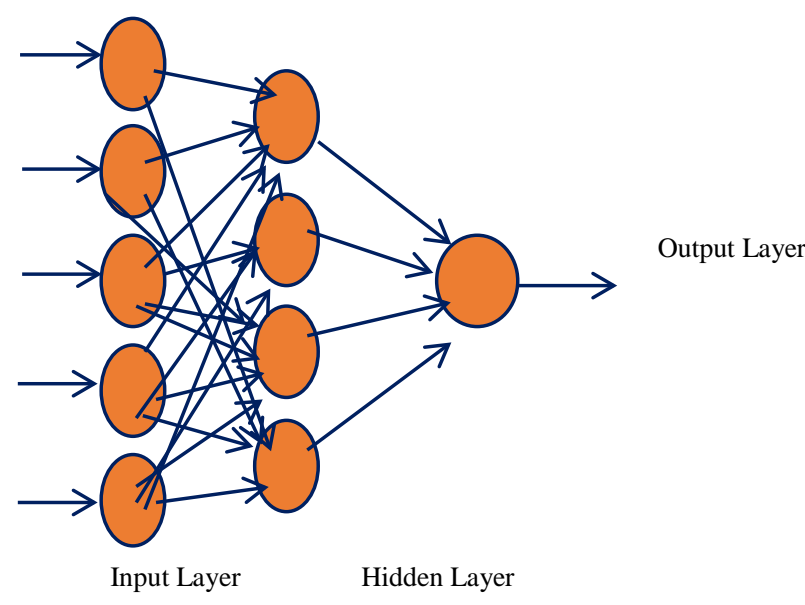

Fig 3. ANN Model of SWM prediction

\section{I. $\quad$ Solid Waste Management Policy}

The waste management responsibility is of the producers. However according with article 25o of the Law n.o7/2007, 5 de Sep, defined by Government, namely by State of Administration and Territory Planning Ministry in article no 9, Cleaning and Sanitation Section, the District Administration service is responsible for the technic support - in the cleaning and sanitation domains namely: remove and deposit in adequate place the waste collected in the District; activities of cleaning, washing and disinfection of streets, pathways and public spaces; cleaning and management of waste deposits, paper wrappers, grass and bush cut, gutter and sinks cleaning, removal of posters, among others.

The solid waste management is defined by specific legislation establishing forms of collection, transport, storage, processing, disposal, recycling or reuse of solid waste. The management of solid waste from domestic and commercial sources are responsibility of local authorities, although the hospital and industrial and waste from construction activities or any other are responsibility of the producer (Environmental Law RDTL, 2011).

\section{CONCLUSION}

Urban Solid Waste is one of the major problems in Dili Community. The waste accumulation is a particular cause of land, water and air pollution, with huge negative effects on the environment and in communities' life quality. However, the waste can be regarded as potential raw materials for production of other products and thus constitute a business opportunity, generating income, creating profit for companies and reducing impacts in health and environment.

The survey reveals a serious problem for the solid waste management that is it's increasing with the population and the income per capita growth. Other problems are the improper disposal of the government and of the community beyond the waste reality; also the lack of sensibilization and divulgation of recycling programs, i.e 3R's program, is a problem, as well as the consumption pattern and the absence of monitoring by the government.

Regarding the way community manages the waste the questionnaires showed that for $94.4 \%$ of respondents the waste is collected from residence and transported to common 
bins; $52 \%$ of respondents dispense household waste recollection, 36\% burns waste. The analysis of the waste impacts reveals that the problems that urgently require a solution are related with health and environment.

About 3'R system application, as a more integrated and adequate system for managing waste in the community, the answer of most respondents was that would accept the system $(89.8 \%)$. About the analysis of the willingness to pay for the service provided by the government $73.8 \%$ said yes. The reasons for that was the possibility to change community behavior and to reduce the impacts on health and environment.

The analysis evaluation of waste management provided by the government reveals that $71.5 \%$ of respondents are satisfied. Regarding the government activities for monitoring this service $55.9 \%$ said that government does not control the rules established. The councils funding for cleaning activities in neighborhoods are already creating habits of waste management in communities and their neighborhoods.

The partnership between Government and the Chinese company will improve the existing system but we suggest the utilization of non-recycled waste to produce energy, because recyclable waste can be introduced in the production chain as secondary raw- material producing a new product. It can also generate employment and income for communities for business, and reduce the exploitation of natural resources.

In conclusion, contributions for an alternative model for waste management in East Timor is: a Government program setting an example practiced by employees on Friday, that applies the waste management 3 'R. A fund for councils to attribute an award or a prize that will motivate waste management in communities. Construction of an infrastructure for waste deposition and treatment. Promote environmental education and sensibilization in schools and in councils. The application of sanctions for ones that not obey to the waste management regulation.

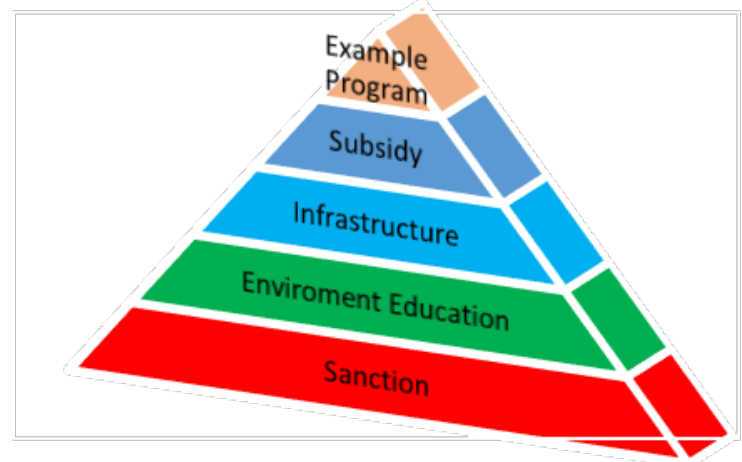

Fig 4. An alternative model of the East Timor Waste Management

In East Timor-Leste we need to create a specific municipal waste management policy, which sets the principles and individual responsibilities. The waste problem solution requires the effort of citizens and government. It is needed to set goals and quantified targets that enable the development of institutional networks that integrate and monitored the system management. It will be important we can improve more study or research to make prevision related of the budget, human resource, logistics and can contribute to Timor Leste Strategic plan

\section{ACKNOWLEDGMENTS}

The author would like to Asia Foundation for financial support and Policy Leader Group.

\section{REFERENCES}

[1] ABNT (ASSOCIAÇÃO BRASILEIRA DE NORMAS TÉCNICAS). "Resíduos Sólidos: classificação”, NBR 10.004. Rio de Janeiro, p.63, 1987.

[2] Bernstein, Janis B, “Alternative approaches to pollution control and waste management regulatory and economic instruments. Urban Management Programme Discussion Paper No.3”, Washington, DC: World Bank, 1991.[Online] Available URL: http://documents.worldbank.org/curated/en/131231468767361425/A lternative-approaches-to-pollution-control-and-waste-managementregulatory-and-economic-instruments

[3] CARVAlho Jesus BIA, “Análise da Política da Gestão de resíduos sólidos em Timor - Leste: Uma Descrição Comparativa dos Sistemas de Gestão de Resíduos em Portugal e Timor - Leste”, Master Thesis at Universidade Minho Portugal, 2012. [Online] Available URL: http://repositorio.untl.edu.tl/handle/123456789/104

[4] http://timor-leste.gov.tl/?p=4144\&n=1\&lang=en

[5] GUPTA, S.et al., "Solid waste management in India: options and opportunities. Resources, Conservation and Recycling”, vol. 24, no.2, pp. 137-154, 1998. Doi:10.1016/S0921-3449(98)00033-0

[6] HELLER, L.; CATAPRETA, C.A.A, "Associação entre coleta de resíduos sólidos domiciliares e saúde, Belo Horizonte (MG), Brasil”. Revista Panamericana de Saúde Publica / Pan American Journal of Public Health, vol. 5, no. 2, pp. 88-96, 1999.

[7] Ministério de Saúde Timor Leste, Update at: Novembro 23, 2014. [Online] Available URL: http://www.moh.gov.tl/?q=node/95

[8] Jornal da República Timor Leste (2008), "Diploma Ministerial RDTL, Updated at: Novembro 23, 2014. [Online] Available URL:http://www.jornal.gov.tl/?mod=artigo\&id=1459

[9] MUELLER, Charles C, "Os economistas e as relações entre o sistema económico e o meio ambiente”, Brasília Editora UNB, 2007.

[10] NUNESMAIA M. F, “GESTION DES DÉCHETS URBAINS SOCIALEMENT INTÉGRÉE . PhD Thesis At: UCP/França, November 2001

[11] Tavares Russo Mário Augusto, "Evolução da gestão dos resíduos sólidos. In Russo, M. A. T. (2003), Tratamento de resíduos sólidos (p.8). Universidade de Coimbra, Updated at Novembro 202014. [Online] Available URL: http://homepage.ufp.pt/madinis/RSol/Web/TARS.pdf

[12] Herdiawan, Junanto. "Rahasia sukses pengelolaan sampah di Jepang”, Available URL: http://olahsampah.com/index.php/manajemen-sampah/39-rahasiasukses-pengolahan-sampah-di-jepang

[13] Rajashekaran S, Pai G.A.V, Neural networks, fuzzy logic and genetic algorithms. In: Ghosh AK (ed) Introduction to artificial intelligence systems 16th print. Prentice Hall of India, India, pp. 11-30, [Online] Avaliable URL:Google Schoolar

[14] Waste Management korea/WasteManagement.pd. [Online] Available URL: http://www.un.org/esa/dsd/dsd_aofw_ni/ni_pdfs/NationalReports/ 